\title{
Diversity of regenerating plants and seed dispersal in two canopy trees from Colombian Amazon forests with different hunting pressure
}

\author{
Victoria Andrea Barrera Zambrano ${ }^{1,2}$, Jenny Zambrano Moncada ${ }^{1,3}$ \& Pablo R. Stevenson ${ }^{1,4}$ \\ 1. Centro de Investigaciones Ecológicas La Macarena, Departamento de Ciencias Biológicas, Universidad de los Andes, \\ Carrera 1 Numero 18 18 -10, Bogotá, Colombia, Tel 0571 3394949-2770; \\ 2. barrera.andreav@gmail.com, \\ 3. je-zambr@uniandes.edu.co; jennyzambrano@hotmail.com \\ 4. pstevens@uniandes.edu.co
}

Received 30-V-2007. Corrected 21-XII-2007. Accepted 31-III-2008.

\begin{abstract}
Hunting may have drastic effects on some populations of frugivores and seed dispersal agents, which in turn may affect patterns of forest regeneration and plant diversity. However, when a species disappears, it is possible that the population of other species increases due to competition release, compensating or not, their ecological roles. The main aim of this study was to measure density compensation in primate communities, their possible effects on seedling and sapling diversity, and compensation of seed removal rates in two canopy trees (Apeiba aspera and Hymenaea oblongifolia). The study site was Amacayacu National Park (Colombian Amazon), where we carried out a census of mammal species using line transect methods in two forests with different levels of hunting pressure. Vegetation plots were used to quantify plant diversity for seedlings and saplings ( $4 \mathrm{~m}^{2}$ and $25 \mathrm{~m}^{2}$ respectively), and fruit traps were set up to estimate seed removal of $A$. aspera and H. oblongifolia. Large primates were less frequently encountered near human settlements, while small primates exhibited the opposite pattern, suggesting a density compensation effect. The diversity of regenerating plants was higher in the forest where large primates occur. Seed removal was higher in forests with large primates for A. aspera, but not for H. oblongifolia. Overall, the results support the hypothesis of density compensation on the primate community; however, there is no strong evidence of ecological compensation in terms of seed dispersal and regeneration in the species studied. Finally, the presence of large seed dispersers (e.g. Lagothrix lagothricha) was associated with higher plant diversity. Rev. Biol. Trop. 56 (3): 1531-1542. Epub 2008 September 30.
\end{abstract}

Key words: Colonization hypothesis, Density compensation, Janzen-Connell hypothesis, Plant diversity, Primate Communities, Seed dispersal.

Central and western Amazonia tropical rain forests have been considered mega-diversity areas (Gentry 1988, Ter Steege et al. 2003), and several hypothesis have tried to explain this fact (Tuomisto et al. 1995, Wills et al. 1997, Schupp et al. 2002, Terborgh et al. 2002). Theories well supported by empirical data include negative density-dependent effects, low competition among young plants, and niche differentiation (Wright 2002). Negative density-dependent effects due to intra-specific competition and the attack of pathogens or predators, have been included in different models to predict changes on spatial patterns, regeneration, and diversity of plant species (Hubbell et al. 1999). Less attention has been focused in the role of inter-specific plant competition involving seed dispersal agents (Peres and van Roosmalen 2002).

Janzen (1970) and Connell (1971) suggested that the survival probability of the offspring below parental trees is low. Plants may experience negative density and distance-dependent effects, caused by pathogens and seed predators, as well as intra-specific competition. According to this theory, in the absence of dispersal mechanisms, some species such as large seeded animal dispersed plants would not be 
able to recruit in the long term and plant diversity would decrease (e.g., Nuñez and Howe 2007). On the other hand, it is possible that a reduction in the rate of seed dispersal may increase plant diversity when seeds of highly competitive species fail to reach adequate regeneration sites and therefore fail to outcompete inferior species (e.g. Tuomisto et al. 1995, Hubbell et al. 1999, Wright 2002).

However, there have been only few studies addressing the role of seed dispersal agents on plant regeneration and diversity patterns (Harms et al. 2000, Nuñez and Howe 2007). Despite that animals disperse a large proportion of the seeds in trees of tropical humid forests (Chapman 1995), it is difficult to predict the ecological effects caused by the reduction or extinction of some groups of dispersers.

Some plant species are known to have a limited number of seed dispersal agents. For example, large seeded endozoochorus plants rely on a few large frugivore species for dispersal (Janson 1983, Peres and van Roosmalen 2002, Stevenson 2007). Even in these plant species it is difficult to predict the effect of a population decrease in large dispersers due to the likelihood of concurrent compensation processes taking place.

Compensation was first defined as "a community level phenomenon where a decrease in the abundance of a species is counterbalanced by an increase in the density of potentially competing species" (Mac Arthur et al. 1972). Peres and Dolman (2000) presented evidence of density compensation in Neotropical primates in forests where hunting on large species was associated with population increase of medium sized monkeys. However, there are few studies addressing the effects of density compensation on ecological processes like frugivory, seed dispersal, and plant recruitment (Bleher and Bohning-Gaese 2001, Poulsen et al. 2002, Cordeiro and Howe 2003, Moran et al. 2004, Stevenson et al. 2005a). When large primates are heavily hunted and the population size of smaller primates increases, it is possible that some plant species will not reach an ecological compensation in terms of seed dispersal, because small animals might not fulfill the role of larger animals (e.g. Peres and Roosmalen 2002, Stevenson et al. 2005a, Nuñez and Howe 2007).

The main aims of this study were: first, to evaluate the existence of density compensation (in terms of population size) in primate communities in two sites with different levels of hunting pressure in Amacayacu National Park, Colombia (Van Leijsen and Vleut 2005). Second, to test the existence of a relationship between hunting of primates and seed removal. Third, to estimate the compensatory effects for seed removal and regeneration, in two canopy species, Apeiba aspera Aubl (Malvacea: Tilioidae) and Hymenaea oblongifolia Huber (Fabaceae: Caesalpinoidea), comparing two sites with different levels of hunting pressure. Small seeds of $A$. aspera are more likely to germinate in gaps, due to light requirements (Stevenson 2006), therefore we focused in particular on seed removal rates and observations on the recruitment of seedlings and saplings near and far from parental plants, as well as in canopy gaps. Finally, our main aim was to quantify the diversity of plants regenerating in areas of contrasting hunting pressure.

It is known that population densities of large primates in general are reduced in heavily hunted areas (Peres 1999a, Peres and Palacios 2007). Based on previous studies in the zone (Van Leijsen and Vleut 2005), we hypothesized that hunting pressure near human settlements would affect primate community composition in such a way that the density of large primates would be reduced, whereas the density of medium and small sized primates (lesshunted) (Redford and Robinson 1987) should increase due to density compensation (Peres and Dolman 2000, Peres and Palacios 2007). Whenever this density compensation occurs, it is also possible to expect compensation in ecological roles. This pattern may vary depending on life history traits of plant species, such as seed size. In particular, small seeded species (e.g. A. aspera) would be more likely to show compensation in seed removal rates than large seeded species (e.g. H. oblongifolia), since 
small seeds can be swallowed by medium and small primates species. Given that large ateline primates are important seed dispersers (Andresen 1999, Stevenson 2000, Russo et al. 2004, Dew 2005, Link and DiFiore 2006) there should be low seed dispersal rates in areas of high hunting pressure.

Finally, according to the dispersal limitation hypothesis (Hubbell et al. 1999), when seeds of highly competitive species fail to reach adequate regeneration sites and therefore fail to outcompete less competitive species, higher plant diversity is expected in places with high dispersal rates of competitive species. Therefore, assuming that large primates are efficient dispersers of this kind of seeds, it should be expected to find higher plant diversity in severely hunted places (i.e., without large primates) than in locations where large primates are common. In contrast, when negative density dependent effects in seedlings are very strong, no-recruitment may be expected for some plant species in the absence of large primate dispersers. Therefore, higher plant diversities would be encountered in areas with high seed dispersal rates (i.e. with large primates).

\section{MATERIALS AND METHODS}

Study site: This study was undertaken during twelve months, between June September 2003, June - November 2005 and February- March 2006, in Amacayacu National Park, in the Colombian Amazon ( $3^{\circ} 02^{\prime}-3^{\circ} 47^{\prime} \mathrm{S}$, $\left.69^{\circ} 54^{\prime}-70^{\circ} 25^{\prime} \mathrm{W}\right)$. Annual mean temperature is $26^{\circ} \mathrm{C}$, average relative humidity $86 \%$, and annual mean rainfall in the closest city is 3200 mm (Rudas et al. 2005). The study was carried out in three sites located on terra firme forests with similar climatic conditions, and with two comparative levels of hunting pressure. Two sites were situated $8 \mathrm{~km}$ away from the Indigenous communities, the other near the visiting centre of Amacayacu National Park, which is located adjacent to two human communities (San Martin de Amacayacu and Mocagua). There is a large history of human occupancy near the visitor's centre, on the border of the Amazon River. Hunting occurs at the sites $8 \mathrm{~km}$ away from the centre, but it is less frequent than at sites nearby human populations. Communities generally hunt up to $10 \mathrm{~km}$ from their villages (Peres and Palacios 2007). Based on field data and interviews Van Leijsen and Vleut (2005) reported that hunting pressure and its frequency in the close vicinity of the community of Mocagua in the past was much more severe than nowadays, reducing or exterminating most of the larger body sized animals close to settlements.

Primates Census: We used line transects to quantify the abundance of primates and other diurnal mammals (Burnham et al. 1980, Buckland et al. 1993, Peres 1999b). Transects varied in length, with an average of $3.95 \pm$ $1.31 \mathrm{~km}$. Total sample length was $190.3 \mathrm{~km}$ in less hunted places and $90.8 \mathrm{~km}$ in the site near communities. The transects were walked at $1.5 \mathrm{~km} /$ hour, between 6 am -10 am and 2 pm -5 pm, during 9 days/transect in average, in the sites far from communities, and 8 days/ transect in average, in the site near communities. For each encounter with mammals during censuses we noted perpendicular distance from first animal detected to trail, species identity, and approximate group size. Population density was calculated for each species using King's method (Krebs 1999):

$$
\mathrm{D}=\mathrm{n} /(2 \mathrm{a}) \mathrm{L},
$$

Where the density (D) is a function of the number of animals (n) seen in the trail, total transect length (L), and the mean perpendicular distance (a). We used King's method, because the number of encounters with some primate species was not enough to employ distance sampling approaches. For further analysis, primate species were grouped in three categories of size: 1. large (5 $\mathrm{kg}$ or more): Lagothrix lagotricha and Alouatta seniculus; 2. medium (1 - $5 \mathrm{~kg}$ ): Callicebus torquatus, Pithecia monachus and Cebus albifrons; and 3. small $(<1 \mathrm{~kg})$ : Saguinus spp. and Saimiri sciureus. 
Plant Diversity: Plots of $4 \mathrm{~m}^{2}$ were placed to quantify seedlings and herbs (without $\mathrm{DBH}$ or $\mathrm{DBH}<1 \mathrm{~cm}$ ) (Duncan and Chapman 2003). Plots of $25 \mathrm{~m}^{2}$ were set up to quantify saplings (DBH between $1-5 \mathrm{~cm}$ ) (Stevenson 2006). To evaluate plant diversity, 114 seedling plots and 111 sapling plots were placed in the proximity of human communities. In the distant site, 100 plots were set up for both seedlings and saplings. The plots were located at each side (randomly) of some of the transects used for primate censuses, every $25 \mathrm{~m}$. Plant species or morpho-species were identified, and diversity estimated using species richness, number of species per stem, and Fisher's diversity index.

Study Species: Seed removal and the escape and colonization hypotheses were evaluated for Apeiba aspera and Hymenaea oblongifolia. The species were chosen due to fruit characteristics and fruit availability (low availability of other fruits). Both species have a mammal dispersal syndrome, without bright color, relatively large, and protected with a hard husk (Janson 1983). The husk limits the access to pulp and seeds by frugivorous birds and their fruits are eaten mainly by capuchins, howler, and woolly monkeys (Stevenson et al. 2000). The study species had different seed size, being larger in $H$. oblongifolia $(\mathrm{X}=1.4$ seeds/fruit; $1.8-2.1 \mathrm{~cm}$. length, $0.8-1.3 \mathrm{~cm}$ width) and smaller in A. aspera (X $=166.8$ seeds/fruit; $0.2-0.3 \mathrm{~cm}$ length) (Stevenson et al. 2000).

Seed Removal: Fruit and seed traps.

To assess seed removal, five fruit traps $\left(1 \mathrm{~m}^{2}\right)$ were set up at $1.5 \mathrm{~m}$ above ground level, under each of six trees of each species. Traps were checked every 15 or 30 days during the fruit crop to quantify and classify its contents (empty husks, whole fruits and seeds). Seed removal rates were estimated as the percentage of seeds going away from parental crowns, based on the total number of fruits produced by the tree, the mean number of seeds per fruit, and the number of seeds found in traps:

$$
\begin{gathered}
\mathrm{SR}=100-(\text { Total number of seeds in } \\
\text { traps } * 100 / \text { Total number of seeds produced })
\end{gathered}
$$

The number of total fruits produced by tree was estimated as the number of entire fruits and husks fund in traps multiplied by the total area of the tree crown (which was estimated through triangle areas). Based on this, the number of seeds produced by each tree was calculated. The total number of seeds in traps included naked seeds and seeds falling within fruits (Stevenson et al. 2005a, Stevenson et al. 2005 b).

Plant Regeneration Plots: In order to quantify regeneration of the two focal species, we used plots for seedlings and saplings $\left(4 \mathrm{~m}^{2}\right.$ and $25 \mathrm{~m}^{2}$ respectively) on six transects per tree. At each transect we set three stations, one at $2 \mathrm{~m}$, one at $10 \mathrm{~m}$ and one at $50 \mathrm{~m}$ away from 20 trees of $H$. oblongifolia and 24 trees of $A$. aspera. Overall, we placed 540 plots around $H$. oblongifolia trees and 648 plots for $A$. aspera in forests near the indigenous communities, and the same distance away from them. Plots of the same size $\left(4 \mathrm{~m}^{2}\right.$ and $\left.25 \mathrm{~m}^{2}\right)$ were used in natural gaps defined by a fallen tree. We quantified regeneration in gaps due to light requirements of $A$. aspera which is a pioneer species with very small seeds (Stevenson 2006). The gaps were a few years old (communication from local assistants). The sampling area used to quantify the regeneration in gaps was 200 $\mathrm{m}^{2}$ for seedlings and $1250 \mathrm{~m}^{2}$ for saplings (50 plots of each size near and far from human settlements).

Statistical Methods: A non- parametric test was used to compare primate densities, due to the lack of normal distributions (Kolmogrov - Smirnov normality test). A G test was performed using Poptools Software (Hood 2000), to assess the relationship between the number of encounters with primates of three different size categories and study site (near or far from human settlements). A comparison for diversity indexes was performed between study sites using either Mann Whitney or T tests. Seed removal results (average $\pm \mathrm{SD}$ ) for each species 
were subjected to normality test and then were compared using an ANOVA test on SPSS10.0 software.

\section{RESULTS}

Primate Censuses: Large primate species were not seen in forests near indigenous communities. In forests far from the communities, they were observed at low densities $(6.23 \pm$ 5.15 individuals $/ \mathrm{km}^{2}$, Fig. 1). The opposite pattern was observed for small primates, which had a higher density in forests near indigenous communities than in forests further away $\left(65.22 \pm 6.88\right.$ vs $32.07 \pm 16.9$ individuals $/ \mathrm{km}^{2}$, Table 1). Differences on total density between places were non significant $(\mathrm{Z}=-0.74, \mathrm{p}=$ $0.94)$, but differences between size categories were observed $\left(\mathrm{X}^{2}=44.9, \mathrm{p}<0.001\right)$ (Fig. 1A). A G-test on primate group encounter frequency between size categories showed similar results. The encounter rate of large and small primates was significantly associated to sites (near or far from indigenous communities) $\left(\mathrm{G}_{\mathrm{w}}=10.36\right.$, $\mathrm{p}=0.006$, Fig. 1B). Medium sized primates showed no contrasting patterns between sites (Table 1).

Plant Regeneration Diversity: All diversity indexes (Fisher's alpha, species richness, species/stem) were higher in forests far from, rather than near to indigenous communities. This pattern was consistently found for both seedlings and saplings (Fig. 2).

Seed Removal: Seed removal rates for A. aspera were higher in places with higher density of large primates (far: $0.48 \pm 0.2$; near: $0.11 \pm 0.18, \mathrm{t}=-3.48, \mathrm{p}=0.005$ ) (Fig. 3A). In contrast, seed removal rates for $H$. oblongifolia were not significantly different between both forests (near: $0.36 \pm 0.25$ vs. far: $0.17 \pm 0.19$; $\mathrm{t}$ $=1.45, \mathrm{p}=0.18)$ (Fig. 3B).

Escape and Colonization Hypotheses: A. aspera seedlings were found exclusively in gaps (Table 2) and sapling density in this species was higher at $50 \mathrm{~m}$ than at $2 \mathrm{~m}$ from
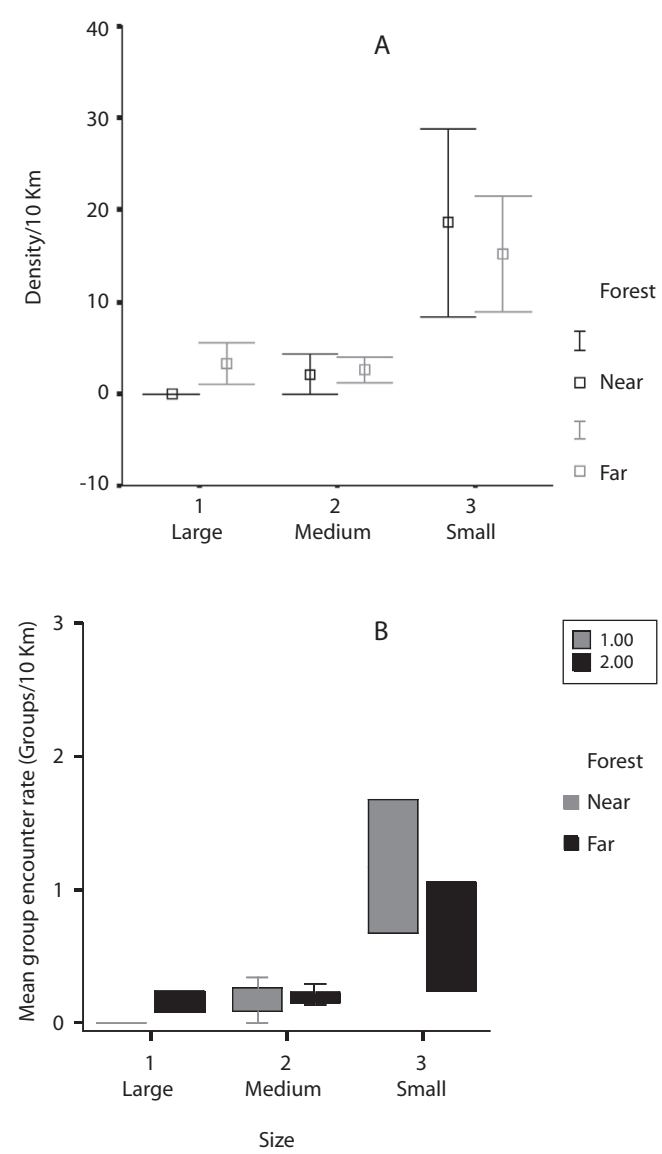

Fig. 1. (A.). Primate density every $10 \mathrm{Km}$ and (B.). and average of encounter of groups every $10 \mathrm{Km}$, (selected by size category) in both sites (near and far $(8 \mathrm{Km})$ from human settlements). Bars shows average \pm 2 standard errors.

parental tree $\left(\mathrm{X}_{\text {saplings }}=0.008 \pm 0.015, \mathrm{X}^{2}=\right.$ $7.5, \mathrm{p}=0.02)$. The density of $H$. oblongifolia seedlings was higher at $2 \mathrm{~m}$ from parental tree and lower at $50 \mathrm{~m}$ (Table $2,\left(\mathrm{X}^{2}=24.7, \mathrm{p}<\right.$ $0,001)$. In contrast, sapling density was higher at $50 \mathrm{~m}$ than at $2 \mathrm{~m}$ from parental tree $\left(\mathrm{X}^{2}=\right.$ $7.3, \mathrm{p}=0.03)$.

\section{DISCUSSION}

We found a higher density of small primates near to indigenous communities than we did further away from them; the opposite pattern was encountered for large primates. This 
findings can be explained by hunting factors (Redford and Robinson 1987, Peres 1999a, Peres and Palacios 2007). Our results support the density compensation hypothesis in terms on size population and biomass. The biomass of all primates was not different between sites $\left(X_{\text {near }}=7.87 \pm 10.57 \mathrm{~kg} / \mathrm{km}^{2}, X_{\text {far }}=9.71 \pm\right.$ $10.83 \mathrm{~kg} / \mathrm{km}^{2}, \mathrm{Z}=-0.96, \mathrm{p}=0.38$ ). Almost all of these primate species, both small and large,
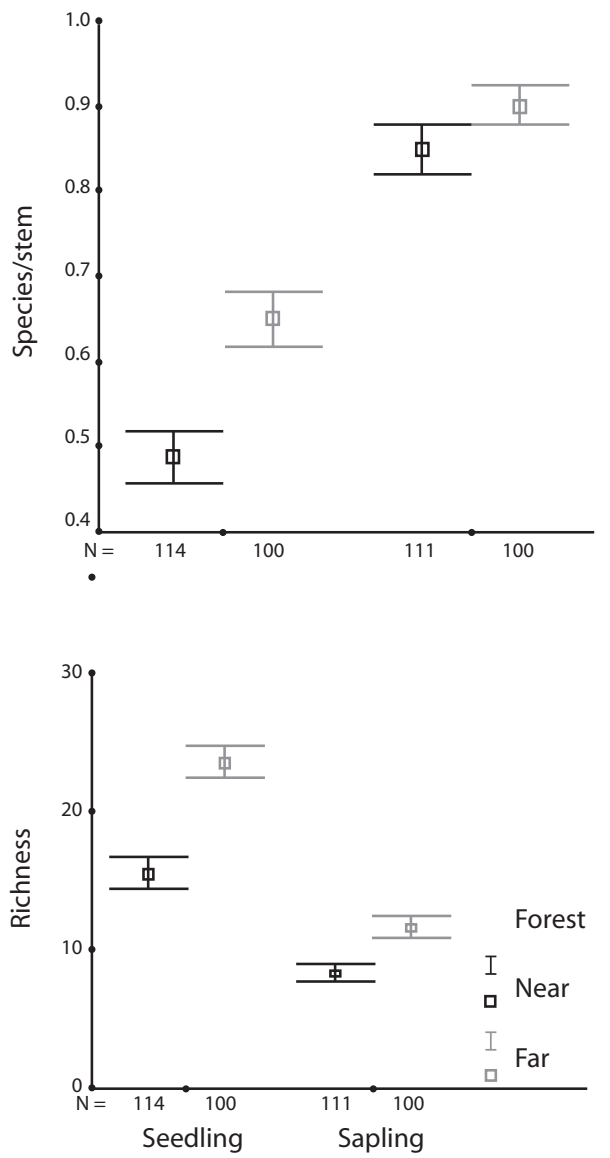

Fig. 2. Average of two diversity index for 114 and 111 seedlings and saplings plots respectively, in site near to human settlements $(\boldsymbol{\Delta})$ and 100 plots for both seedlings and saplings, in site far from human settlements $(\bullet)$. (Seedlings: Fisher's alpha $\mathrm{near}_{\text {r }}=15$, alpha $_{\text {far }}=2238 ; \mathrm{z}=-3.32, \mathrm{p}=0.001$; Species richness: $\mathrm{x}_{\text {near }}=15.53, \mathrm{x}_{\mathrm{far}}=23.49 ; \mathrm{z}=-8.51$, $\mathrm{p}<0.01$; Species/stem: $\mathrm{x}_{\text {near }}=0.49, \mathrm{x}_{\text {far }}=0.65 ; \mathrm{F}=0.05$, $\mathrm{p}<0.001$. Saplings: Fisher's: alpha $\mathrm{near}=2372.3$, alpha $\mathrm{far}_{\mathrm{f}}=$ 71034.4; $\mathrm{z}=-4.45, \mathrm{p}<0.001$; Species richness: $\mathrm{x}_{\text {near }}=8, \mathrm{x}_{\text {far }}$ $=12 ; \mathrm{z}=-6.04, \mathrm{p}<0.001 ;$ Species $/$ stem: $\mathrm{x}_{\text {near }}=0.85, \mathrm{x}_{\mathrm{far}}=$ $0.9 ; \mathrm{z}=-2.51, \mathrm{p}=0.012$ ). include significant amounts of fruit in their diets (Terborgh 1983, Guillotin et al. 1994, Stevenson et al. 2000) therefore, competition between them is possible. If large primates become absent, smaller primates could consume more resources and increase their densities (e.g., Peres and Palacios 2007). Preliminary data about primate communities in the study zone are not yet sufficient to confirm if primate community structure has always been the same (higher density of small primate compared with large primate density). Defler (2001) studied a primate community on the north zone of Amacayacu National Park, more than $40 \mathrm{~km}$ from any human settlement and found a higher frequency of encounters with small primates (Saguinus spp. and Saimiri sp.) compared to
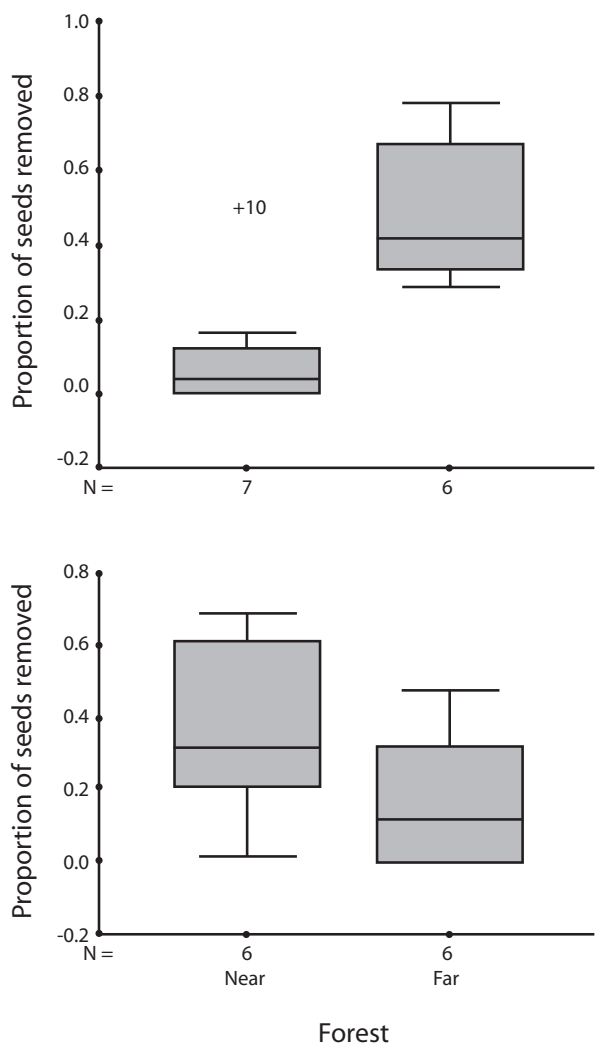

Fig. 3. Proportion of seed removal rates, according to estimates from fruit traps located under six trees of each species in both sites (near and far $(8 \mathrm{Km})$ from human settlements). (A.). A. aspera. and (B.). H. oblongifolia. 
TABLE 1

Density, total encounters and biomass of primates in both sites of study

\begin{tabular}{|c|c|c|c|c|c|c|c|c|}
\hline \multirow[b]{2}{*}{ Size } & \multirow[b]{2}{*}{ Species } & \multirow[t]{2}{*}{$\begin{array}{l}\text { Body mass } \\
\quad(\mathrm{Kg})\end{array}$} & \multicolumn{2}{|c|}{$\begin{array}{l}\text { Density } \\
\left(\mathrm{Ind} / \mathrm{km}^{2}\right)\end{array}$} & \multicolumn{2}{|c|}{ T. Encounters } & \multicolumn{2}{|c|}{$\begin{array}{l}\text { Biomass } \\
\left(\mathrm{Kg} / \mathrm{km}^{2}\right)\end{array}$} \\
\hline & & & Near & Far & Near & Far & Near & Far \\
\hline Large & Alouatta seniculus & 6.60 & 0.00 & $2.02 \pm 4.74$ & 0.00 & 9.00 & 0.00 & 15.56 \\
\hline \multirow[t]{2}{*}{ Large } & Lagothrix lagothricha & 6.75 & 0.00 & $4.30 \pm 5.33$ & 0.00 & 3.00 & 0.00 & 33.84 \\
\hline & Total & & 0.00 & 6.32 & 0.00 & 12.00 & 0.00 & 49.39 \\
\hline Medium & Cebus albifrons & 2.40 & 0.00 & $1.10 \pm 3.19$ & 0.00 & 6.00 & 0.00 & 3.08 \\
\hline Medium & Callicebus torquatus & 1.40 & $2.87 \pm 2.19$ & $3.08 \pm 5.57$ & 4.00 & 11.00 & 3.35 & 5.03 \\
\hline \multirow[t]{2}{*}{ Medium } & Pithecia monachus & 2.20 & $5.51 \pm 6.35$ & $0.93 \pm 3.68$ & 2.00 & 5.00 & 10.10 & 2.40 \\
\hline & Total & & 8.38 & 5.12 & 6.00 & 22.00 & 13.45 & 10.51 \\
\hline Small & Saguinus spp & 0.49 & $35.05 \pm 8.39$ & $22.16 \pm 19.16$ & 20.00 & 41.00 & 14.31 & 12.67 \\
\hline \multirow[t]{2}{*}{ Small } & Saimiri sciureus & 0.90 & $30.17 \pm 6.9$ & $9.91 \pm 10.99$ & 8.00 & 9.00 & 22.62 & 10.41 \\
\hline & Total & & 65.22 & 32.07 & 28.00 & 50.00 & 36.94 & 23.07 \\
\hline
\end{tabular}

Density (individuals $/ \mathrm{km}^{2}$ ), total of primate encounters, and biomass (in $\mathrm{Kg}$ based on body weight reported by Peres and Dolman 2000; Peres and van Roosmalen 2002; Peres 1994b; Freese et al. 1982; Defler 2003) in both sites (near and far $(8 \mathrm{~km})$ from human settlements). Densities and biomass reported for site far from human settlements, take into account data from Van Leijsen and Vleut (2005), registered in the same place during the year 2004 and also some data taken by Maldonado during the year 2006.

TABLE 2

Density of seedlings and saplings of $\mathrm{A}$. Aspera and $\mathrm{H}$. oblongifolia

Forest $\quad$ Species

A. aspera

Gap

Mature forest

Gap

Mature forest

Distance from parent tree

$2 \mathrm{~m}$

$10 \mathrm{~m}$

$50 \mathrm{~m}$

$2 \mathrm{~m}$

$10 \mathrm{~m}$

$50 \mathrm{~m}$

A. aspera
Seedlings

Near

$0.075 \pm 0.129$

0.00

0.00

$0.203 \pm 0.289$

$0.187 \pm 0.009$

$0.0008 \pm 0.007$

$0.00073 \pm 0.008$

$\begin{array}{ccccc}0.00 & 0.00 & 0.00 & 0.00 \\ 0.00 & 0.00 & 0.0015 \pm 0.038 & 0.001 \pm 0.026 \\ \text { H. oblongifolia } & 0.00 & 0.00 & 0.0015 \pm 0.028 & 0.0017 \pm 0.028 \\ & & & & \\ & 0.48 \pm 0.87 & 0.33 \pm 0.47 & 0.00 & 0.00 \\ & 0.12 \pm 0.133 & 0.06 \pm 0.07 & 0.0013 \pm 0.027 & 0.00 \\ & 0.01 \pm 0.008 & 0.17 \pm 0.003 & 0.0013 \pm 0.132 & 0.0022 \pm 0.043\end{array}$

Density (individuals $/ \mathrm{m}^{2}$ ) of seedlings and saplings (average $\pm \mathrm{SD}$ ) of A. aspera and H.oblongifolia in gaps and mature forest, and Density (individuals $/ \mathrm{m}^{2}$ ) of seedlings and saplings of A.aspera and H. oblongifolia at three different distances from parent tree, in both sites (near and far $(8 \mathrm{~km})$ from human settlements). 
large primates (Lagothrix sp, Alouatta $s p$ ). However, the frequency of small primates was lower $(0.64 \mathrm{ind} / 10 \mathrm{~km})$ than the one found in our study area in proximity of human settlements $(0.81 \mathrm{ind} / 10 \mathrm{~km})$. These results are also in agreement with both the reduction of large primate abundance near human settlements and density compensation effects in terms of population size of small primates. Furthermore, in an analysis of 101 Neotropical forest sites, Peres and Palacios (2007) found a negative correlation between the level of hunting pressure and the density of large primates. However, the pattern for small Saguinus species was the opposite. Nevertheless, there is no compensation in terms of biomass, because of the disproportionate contribution of large body animals in tropical forests.

The increase of small primates was unexpected in the sense that, in other communities, the medium sized primates show the largest density compensation effect (Peres and Dolman 2000). This pattern was explained by the similar diet between large and medium sized primates. Stevenson et al. (2000) found relatively high indices of fruit diet overlap between $C$. apella and large atelines, such as A. belzebuth and L. lagothricha, in Tinigua National Park. Furthermore, Peres and Dolman (2000) suggested a tendency of smaller species to compensate the absence of large species is higher in "low-productive forests", which may be the case of our study site.

Although small primates compensate densities in the reduction of large primate populations, the results of this study do not support the hypothesis of compensation in ecological roles such as in seed removal rates. The hypothesis which proposes that sapling diversity can decrease under high seed dispersal rates due to competition was not supported. Given that large ateline primates play the most important roles in seed dispersal, as demonstrated in other Neotropical forests (Stevenson 2007), it is likely that seed dispersal rates at the community level would decrease in their absence. Our results indicate that in the absence of large primates the diversity of regenerating plants is lower, suggesting they play important roles on forest regeneration and diversity patterns (Ganzhorn et al. 1999, Webb and Peart 2001, Peres and Van Roosmalen 2002, Cordeiro and Howe 2003). It is possible that the differences in diversity are caused by other factors not controlled in our study (i.e. microhabitat differences, seed predation rates, top carnivores which might control seed and seedling predators etc.), nonetheless it is important to remark that the absence of large primates does not appear to cause any noticeable rise in regenerating plant diversity as expected by the dispersal limitation hypothesis (Hubbell et al. 1999).

It has been demonstrated that large primates can disperse large seeds, which other species cannot (Peres and van Roosmalen 2002, Stevenson et al. 2005b). As a consequence, when their populations diminish or disappear, several plant species would have fewer possibilities to be dispersed and recruited, causing a decrease in local diversity. The results of our study are similar to those reported by Howe and Nuñez (2007) who found a 55\% less richness and $60 \%$ lower density of plant species dispersed by large primates in a Peruvian hunted forest compared to an unprotected one. In conclusion, several of the mechanisms which have been suggested to maintain diversity on tropical forests (Wright 2002) are closely related to seed dispersal, and agree with the results of this study; if the process of seed dispersal fails because of the large primate absence, plant diversity will diminish.

The results of this study did not support the ecological compensation hypothesis in terms of seed removal for A. aspera, which had higher seed removal rates in forests where large primate density is higher. Due to the fruit characteristics of $A$. aspera (hard husk), it is possible that other fugrivores, different to large primates, do not have access to fruit pulp and therefore can not disperse its seeds. Similar work in Tinigua National Park, which has a higher density of large primates, showed a higher seed removal rate for this species (Stevenson 2002). Interestingly, this difference is not significant 
when compared to the forest far from indigenous communities in Amacayacu $\left(\mathrm{X}_{\text {Amacayacu }}\right.$ $=44.67 \pm 20.4$ proportion of seed dispersed. $\mathrm{X}_{\text {Tinigua }}=52.39 \pm 21.38$ proportion of seed dispersed; $p=0.208 \mathrm{~F}=2.67$ ). This suggests that even a low population of large primates may have effects in seed removal rates.

Seedlings of $A$. aspera were found exclusively in gaps. Density $\left(\mathrm{X}_{\text {near }}=0.075 \mathrm{ind} / \mathrm{m}^{2}\right.$, $X_{\text {far }}=0.095 \mathrm{ind} / \mathrm{m}^{2}$ ) was slightly higher in forest far from indigenous communities than close to them. This result applies for sapling density too $\left(\mathrm{X}_{\text {near }}=0.0048 \mathrm{ind} / \mathrm{m}^{2}, \mathrm{X}_{\text {far }}=0.0064 \mathrm{ind} /\right.$ $\mathrm{m}^{2}$ ). These findings support the colonization hypothesis, and also suggest that large primates could be responsible for the difference in seed removal rates. For $H$. oblongifolia, seed removal was not significantly different between forests. It has been reported that small primates may disperse large seeds (Garber 1986) at a low frequency. It is therefore possible that small primates may be eating and dispersing the seeds of this plant species. However, it has also been reported that parrots consume and predate seeds of H. oblongifolia (Stevenson et a.l 2000). It would be interesting to know the composition and abundance of the communities of parrots in the sites of study to predict if they are responsible for the disappearance of seeds.

Regeneration data are in accordance with the Janzen-Connell hypothesis, as seed dispersal was proved important for the recruitment of $H$. oblongifolia. Without considering the disperser assemblage, sapling density was higher far from parental trees. Interestingly, seedling density was higher near to, rather than far from parental trees, in areas of heavy hunting. This suggests low seed removal rates and low transition probabilities between the seedling and sapling stages below parental trees. The fact that saplings showed the opposite patterns suggests that negative density or distance-dependent effects occur in that transition period (Stevenson 2006), and indicate potential recruitment problems in the absence of legitimate seed dispersers. Nevertheless, it is important to take into account that in forests far from indigenous communities some seed predators like Tayassu tajacu, are in higher proportions and could be responsible for the regeneration results obtained. Therefore, when seed and seedling predation rise in forests far from indigenous communities, differences between forests are less evident. Silman et al. (2003) showed that in absence of a peccary species in Cosha Cashu biological station, seedling density of Astrocaryum murumuru increased 1.7 times compared with years when the same peccary species was present. Thus, this demonstrates than only one seed predator may have significant effects on plant regeneration.

Other studies focusing on dispersal and regeneration of large and small seeded plants under hunting pressure (eg. Dirzo et al. 2007) reveal different patterns. Beckman and MullerLandau (2007) reported primary removal of Cordia bicolor (medium seeds) 43\% lower in hunted sites, while primary removal of Oenocarpus mapora (large seeds) was not different between sites. On the other hand, secondary removal of $O$. mapora was $59 \%$ lower in hunted sites, while secondary removal of $C$. bicolor showed no differences. Thus, the study suggests that defaunation affects seed dispersal and the regeneration of different plant species in different ways, and that seed size is not a reliable predictor of the impacts of hunting. It is therefore important to consider that between the time of seed removal and plant recruitment there are several stages, such as seed predation and secondary seed dispersal factors, which were not measured in this study. The net effects of humans on seed predators and secondary dispersers should be directly considered to have a better understanding of the complex process that affects plant regeneration (Guariguata and Pinard 1998). In addition, it is necessary to study more plant species with small and large seeds to understand the effects of primate densities on seed dispersal and regeneration processes (Stoner et al 2007).

\section{ACKNOWLEDGMENTS}

We thank the Amacaycu National Park staff and the indigenous communities of 
Mocagua, San Martin de Amacayacu, Zaragoza and Macedonia, where the field work was done and also the indigenous research group who collaborated with data collection. We thank "The Woolly Monkey Project" for its participation in this research and Angela Parrado for her collaboration during this investigation. We thank Daniel Cadena, Julian Palomino, and the CIEM students for their comments and contributions to the final version of this manuscript. The research was founded by Tropenbos Fundation and La Facultad de Ciencias and el Departamento de Biología de la Universidad de los Andes.

\section{RESUMEN}

La cacería ha tenido fuertes efectos en algunas poblaciones de frugívoros y dispersores de semillas, lo cual en consecuencia puede afectar los patrones de diversidad de plantas y regeneración del bosque. Sin embargo, es posible que extinciones locales promuevan el incremento de otras especies, que pueden o no compensar roles ecológicos. El principal objetivo de este estudio fue examinar la posibilidad de compensación por densidad en las comunidades de primates y sus posibles efectos sobre la diversidad de plántulas y juveniles, así como también la remoción de semillas de dos árboles (Apeiba aspera e Hymenaea oblongifolia). El trabajo fue realizado en el Parque Nacional Natural Amacayacu (Amazonas - Colombia). Hicimos censos de mamíferos usando transectos lineales en dos bosques con diferentes presiones de cacería. Además, levantamos parcelas de vegetación para plántulas y juveniles $\left(4 \mathrm{~m}^{2}\right.$ y $25 \mathrm{~m}^{2}$ respectivamente), y ubicamos trampas de frutos bajo al menos seis árboles de cada especie, en cada bosque, para estimar la remoción de semillas. Los encuentros con primates grandes fueron menos frecuentes en bosques cerca de las comunidades indígenas, mientras que para los primates pequeños el patrón fue contrario, sugiriendo un efecto de compensación por densidad. Por otra parte, la diversidad de plántulas y juveniles fue más alta en bosques donde la densidad de primates grandes es mayor. La remoción de semillas fue mayor en bosques con mayor densidad de primates grandes para A. aspera, pero para $H$. oblongifolia las diferencias entre bosques no fueron significativas. En general, los resultados de este estudio apoyan la hipótesis de compensación por densidad en la comunidad de primates, sin embargo, no hay evidencia fuerte de compensación ecológica en términos de dispersión de semillas y regeneración. Finalmente, la presencia de dispersores grandes (ej. Lagothrix lagothricha) estuvo asociada con una mayor diversidad de plantas.

Palabras clave: hipotesis de la colonización, compensación por densidad, hipótesis de Janzen-Connell, diversidad de plantas, comunidad de primates, dispersión de semillas.

\section{REFERENCES}

Andresen, E. 1999. Seed dispersal by monkeys and the fate of dispersed seeds in a Peruvian rain forest. Biotropica 31: 145-158.

Beckman, N. \& H. C. Muller-Landau. 2007. Differential effects of hunting on pre-dispersal seed predation and primary and secondary seed removal of two Neotropical tree species. Biotropica 39: 328-339.

Bleher, B. \& K. Bohning-Gaese. 2001. Consequences of frugivore diversity for seed dispersal, seedling establishment and the spatial pattern of seedlings and trees. Oecologia 129:385-394.

Buckland, S.T., D.A. Elston. 1993. Empirical models for the spatial distribution of wildlife. J. appl ecol. 30: 478-495.

Burnham, K.P., D.R. Anderson \& J.L. Laake.. 1980. Estimation of density from line transect sampling of biological populations. Wildlife Monographs 7-202.

Chapman, C.A. 1995. Primate seed dispersal: coevolution and conservation implications. Evolutionary Anthropology 4: 74-82.

Cordeiro, N.J. \& H.F. Howe. 2003. Forest fragmentation severs mutualism between seed dispersers and an endemic African tree. PNAS-USA 100: $14052-$ 14056.

Connell, J.H. 1971. On the role of natural enemies in preventing competitive exclusion in some marine animals and in rain forest trees. p. 298-312 In P.J. den Boer \& G.R. Gradwell, (eds). Dynamics of populations. Pudoc, Wageningen, Holland.

Defler, T.R. 2001. Diversity and abundance of species in eastern Colombia. Memories of the XVIII th Congress of the International Primatological Society. Adelaide, Australia.

Dew, J.L. 2005. Foraging, food choice, and food processing by sympatric ripe-fruit specialists: Lagothrix lagotricha poeppigii and Ateles belzebuth belzebuth. Int. j. Primatol. 26: 1107-1135.

Duncan, R.S. \& C.A. Chapman. 2003. Consequences of plantation harvest during tropical forest restoration in Uganda. Forest Ecol. Manag. 173: 235-250.

Muller-Landau, H.C. 2007. Predicting the long-term effects of hunting on plant species composition and diversity in tropical forests. Biotropica 39: 372-384.

Garber, P.A. 1986. The ecology of seed dispersal in 2 species of callitrichid primates (saguinus mystax and saguinus fuscicollis). Am. J. primatol. 10: 155-170. 
Ganzhorn. J.U., P.P. Lowry II, E.G. Schatz, S. Sommer. 2001. The biodiversity of Madagascar: one of the world's hottest hotspots on its way out. Oryx 35: 346-348.

Gentry, A.H. 1988. Changes in Plant Community Diversity and Floristic Composition On Environmental and Geographical Gradients. Ann. Missouri Bot. Garden 75: 1-34.

Guariguata, M.R. \& M.A. Pinard. 1998. Ecological knowledge of regeneration from seed in neotropical forest trees: implications for natural forest management. Forest Ecol. Manag.112: 87-99.

Guillotin, M., G. Dubost \& D. Sabatier. 1994. Food Choice and Food Competition Among the 3 Major Primate Species of French-Guiana. J. Zool. 233: 551-579.

Harms, K.E., S.J. Wright, O. Calderon, A. Hernandez \& E.A. Herre. 2000. Pervasive density-dependent recruitment enhances seedling diversity in a tropical forest. Nature 404: 493-495.

Howe, H.F. \& J. Smallwood. 1982. Ecology of seed dispersal. Ann. Rev ecolog. Syst. 13: 201-218.

Hubbell, S.P., R.B. Foster, S.T. O’brien, K.E. Harms, R. Condit, B. Wechsler, S.J. Wrightand S.L.de lao, 1999. Light-gap disturbances, recruitment limitation, and tree diversity in a neotropical forest. Science 283: 554-557.

Janson, C.H. 1983. Adaptation of fruit morphology to dispersal agents in a neotropical forest. Science 219: 187-189.

Janzen, D.H. 1970. Herbivores and the number of tree species in tropical forests. Am. nat. 104: 501-528.

Krebs, C.J. 1999. Ecological Methodology. AddisonWelsey, San Francisoc, California, U.S.A.

Link, A. \& A. Di Fiore. 2006. Seed dispersal by spider monkeys and its importance in the maintenance of neotropical rain-forest diversity. J. Trop. Ecol. 22: 235-246.

Maldonado, A.M. 2007. The Woolly Monkey Project: Status and conservation of Primates in Amacayacu National Park, Colombian Amazon: A community based research project. Woolly Monkey Project: Bogotá.

McArthur, R.H. 1972. Density compensation in island faunas. Ecology 53: 330 .

Moran, C., C.P. Catterall, R.J. Green \& M.F. Olsen. 2004. Functional variation among frugivorous birds: impli- cations for rainforest seed dispersal in a fragmented subtropical landscape. Oecologia 141: 584-595.

Nuñez-Iturri, G. \& H. F. Howe. 2007. Bushmeat and the fate of trees with seeds dispersed by large primates in a lowland rainforest in western Amazonia. Biotropica 39: 348-354.

Peres, C.A. 1999a. Effects of subsistence hunting and forest types on the structure of amazonian primate communities. p. 268-283 In, J.G. Fleagle, C.H. Janson \& K.E. Reed, (eds.). Primate Communities. Cambridge University, Cambridge, United Kingdom.

Peres, C. 1999b. General guidelines for standardized linetransect surveys of tropical forest primates. Neotrop. Primates 7:11-16.

Peres, C.A. \& P.M. Dolman. 2000. Density compensation in neotropical primate communities: evidence from 56 hunted and nonhunted amazonian forests of varying productivity. Oecologia 122: 175-189.

Peres, C.A. \& M. Van Roosmalen. 2002. Primate frugivory in two species-rich neotropical forests: implications for the demography of large-seeded plants in overhunted areas. pp. 407-421 In Levey, D.J., W.R. Silva \& M. Galetti. (eds.). Seed dispersal and frugivory: ecology, evolution and conservation. $\mathrm{CAB}$, London

Peres, C.A. \& E. Palacios. 2007. Basin-Wide effects of Game Harvest on Vertebrate Population Densities in Amazonian Forests: Implications for AnimalMediated Seed Dispersal. Biotropica 39: 304-315.

Poulsen, J.R., C.J. Clark, E.F. Connor \& T.B. Smith. 2002. Differential resource use by primates and hornbills: implications for seed dispersal. Ecology 83: 228240 .

Redford, K.H. \& J.G. Robinson. 1987. The game of choice - patterns of indian and colonist hunting in the neotropics. Am. Anthropol 89:650-667.

Rudas, A., A. Prieto Cruz, C.M. Taylor \& R. Ortiz. 2005. Flórula del Parque Nacional Natural Amacayacu, Amazonas, Colombia. Missouri Botanical Garden, Saint Louis, Missouri, USA

Russo, S.E. \& C.K. Augspurger. 2004. Aggregated seed dispersal by spider monkeys limits recruitment to clumped patterns in Virola calophylla. Ecol. Lett. 7: 1058-1067.

Schupp, E., T. Milleron \& S.E. Russo. 2002. Dissemination limitation and the origin and maintenance of speciesrich tropical forests. p. 17-33 In D.J. Levey, W.R. 
Silva \& M. Galetti (eds.). Seed dispersal and frugivory: ecology, evolution, and conservation, New York, USA.

Silman, M.R., J.W. Terborgh \& R.A. Kiltie. 2003. Population regulation of a dominant-rain forest tree by a major seed-predator. Ecology 84: 431-438.

Stevenson, P.R. 2000. Seed dispersal by woolly monkeys (Lagothrix lagothricha) at Tinigua National Park, Colombia: dispersal distance, germination rates, and dispersal quantity. Am. J. primatol. 50: 275-289.

Stevenson, P.R. 2002. Frugivory and seed dispersal by woolly monkeys at Tinigua National Park, Colombia. $\mathrm{PhD}$ Thesis. State University of New York at Stony Brook, New York, USA p. 411.

Stevenson P.R. 2006. A test of the escape and colonization hypotheses for zoochorous tree species in a Western Amazonian forest. Plant Ecology DOI 10.1007/ s11258-006-9205-5.

Stevenson, P.R. 2007. Estimates of the number of seeds dispersed by a population of primates in a lowland forest in western Amazonia. p. 340-362. In A. J. Dennis, E.W., Schupp, R. J. Green \& D. W. Westcott (eds). Seed dispersal: theory and its application in a changing world. Wallingford, United Kingdom.

Stevenson, P.R., Quiñones, M.J. \& Ahumada, J. 2000. Influence of fruit availability on ecological overlap among four neotropical primates at Tinigua National Park, Colombia. Biotropica 32: 533-544.

Stevenson, P.R., M. Pineda \& T. Samper. 2005a. Influence of seed size on dispersal probabilities by woolly monkeys (Lagothrix lagothricha) at Tinigua National Park, Colombia. Oikos 110: 435-440.

Stevenson, P.R., A. Link. \& B.H. Ramirez. 2005b. Frugivory and seed fate in Bursera inversa (Burseraceae) at Tinigua Park, Colombia: implications for primate conservation. Biotropica 37: 431-438.

Stoner, K.E., P. Riba-Hernández, K. Vulinec \& J.E. Lambert. 2007. The role of mammals in tropical forest regeneration and some possible consequences of their elimination: An overview. Biotropica 39: 316-327.
Terborgh, J. 1983. Five new world primates. A study on comparative ecology. Princeton University, Princeton New Jersey, USA p. 260.

Terborgh J, N. Pitman M. Silman, H. Schicheter \& V.P. Nuñez 2002. Maintenance of tree diversity in tropical forests. p. 1-17. In Seed dispersal and frugivory: Ecology, Evolution and Conservation . Levey DJ, Silva WR and Galetti M (eds), Oxford University, London, United Kingdom.

Ter Steege, H., N. Pitman, D. Sabatier, H. Castellanos, P. Van der Hout, D.C. Daly, M. Silveira, O. Phillips, R. Vasquez, T. Van Andel, J. Duivenvoorden, A.A. De Oliveira, R. Ek, . Lilwah, R. Thomas, J. Van Essen, C. Baider, P. Maas, S. Mori, J. Terborgh, P.N. Vargas, H. Mogollon, \& W. Morawetz. 2003. A spatial model of tree alpha-diversity and tree density for the Amazon. Biodiv. Conserv. 12: 2255-2277.

Tuomisto, H., K. Ruokolainen, R. Kalliola, A. Linna, W. Danjoy \& Z. Rodriguez 1995. Dissecting amazonian biodiversity. Science 269: 63-66.

Van Leijsen Jeroen \& Vleut Ivar. 2005. Impact of an indigenous community on the woolly monkey (lagothrix lagothrichia) and 7 other primate species in the amazonian rainforest, Colombia. MsC Thesis. Wageningen University, The Netherlands.

Webb C.O. \& D.R. Peart. 2001. High seed dispersal rates in faunally intact rain forest: theoretical and conservation implications. Ecology Letters 4: 491-499.

Wills, C., R. Condit, R.B. Foster \& S.P. Hubbell. 1997. Strong density- and diversity-related effects help to maintain tree species diversity in a neotropical forest. PNAS-USA 94: 1252-1257.

Wright, J.S. 2002. Plant diversity in tropical forests: a review of mechanisms of species coexistence. Oecologia 130: 1-14.

\section{INTERNET REFERENCE}

Hood, G.M. 2000. Poptools-software for the analysis of ecological models. Version 2.5.5. (http://www.cse. csiro.au/poptools). 